\title{
The Role of Spontaneous and Augmented Microflora in Cleaning Oil-Contaminated Loamy Gray Soils of Southern Kazakhstan
}

\section{Aigul Myrzakhanovna Sattarova}

Department of Ecology and Biotechnology

\author{
M. Auezov named South Kazakhstan State University
}

Issayeva Akmaral Umirbekovna

Department of Ecology and Biotechnology

Doi:10.5901/mjss.2015.v6n1s2p103

\author{
M. Auezov named South Kazakhstan State University
}

\begin{abstract}
Kazakhstan is one of the major oil producing and processing countries. Unfortunately, along with the growing volume of processed crude oil intensifies the problem of environmental pollution. In this context, the aim of this work was to study the role of microorganisms in the bioremediation of oil-contaminated loamy gray soils of South Kazakhstan. The studies were allocated 2 active strains of microorganisms Micrococcus luteus IS16 and Micrococcus varians IS41, which in vitro degraded $99.3 \%$ contributed by $2.0 \%$ kumkol oil. In real soil and climatic conditions of spontaneous microflora reduced content Kumkol oil by $39.6 \%$, augmented microorganisms degraded $57.3 \%$ of oil, $92.8 \%$ of diesel fuel for 2 months.
\end{abstract}

Keywords: Bioremediation of oil-contaminated soils, spontaneous and augmented microflora

\section{Introduction}

The extraction of natural resources, oil is associated with the destruction of soil and pollution of natural landscapes, which is associated with the use of heavy equipment and the inevitable hit the ground petroleum, petroleum products and related pollutants (Baker JM, 1983, Anozie O., and Onwurah I.N.E. 2001). The intensive use of petroleum products in the industry also causes environmental problems associated with land and water pollution. Contamination of soil and water all types of petroleum products is a real ecological disaster ecosystem: changing relations between groups of microorganisms, changes the direction of metabolism, suppresses the vital processes of breathing and selfpurification(Admon S. et al, 2001). Poisoned oil soil and water almost can`t independently be cleansed of oil pollution the natural decomposition of oil and petroleum products under normal conditions is extremely slow, since higher concentrations of hydrocarbons suppress any self-cleaning activity of the soil and water, accumulate in the ecosystem difficult-products, seriously impeding the self-cleaning and self-healing (Dibble, JT and Bartha R., 1979, Namkong, W. Et al., 2003, Chaineau, $\mathrm{CH}$ et al. 2005).

Over the past decades the interest of scientists to study the hydrocarbon-oxidizing microorganisms increased markedly. Numerous studies related to the biotransformation, biodegradation and bioremediation of petroleum hydrocarbons, and the use oil oxidizing microorganisms organisms for environmental clean-up today occupy a central place in the petroleum microbiology (Ainon, H. et al., 2006, Embar, K. et al., 2006, Azlinah, MS et al., 2008). The result of scientific work in this area began to develop in different bioremediation of oil, including oil destructors active strains and their consortia (Gallego JL et al, 2001, llyina, A.et al, 2003, Obayori OS et al, 2009). In addition to viable microbial cells they contain a variety of additives in various combinations (Obuekwe CO et al, 2008, Milic JS et al, 2009, Issayeva AU et al, 2012).

Reclamation of oil-contaminated soils is reduced substantially to eliminate interference to the success of soil microorganisms(Mishra S. et al, 2001, Chaineau C.H. et al, 2003). There are three most common phase transformation of the oil in the soil, all of them are somehow related to the activity of soil microorganisms:

- Physico-chemical, and in particular, microbial degradation of aliphatic hydrocarbons;

- Microbiological destruction of low-molecular structures of different adhesives, neoplasms resinous substances;

- The transformation of high-molecular compounds: resins, asphaltenes, polycyclic hydrocarbons (Vega-Larquin C. et al, 2001, Okoh Al, 2006). 
The main feature characterizing this physiological groups of microorganisms is their ability to metabolize petroleum hydrocarbons as the sole source of carbon nutrition. In considering the aspects of microbiological degradation of oil components are divided into saturated hydrocarbons with normal and branched olefins, cycloalkanes, aromatic hydrocarbons, asphaltenes (phenols, fatty acids, ketones, ethers, porphyrins), and resin: pyridines, carbazoles, sulfoxides, amides. The chemical composition and structure of the individual components of the oil determines the characteristics of their utilization by microorganisms.

In general, low molecular weight hydrocarbons, petroleum fractions in a relatively short period of time are removed from the soil: one due to evaporation, and the other at the expense of metabolic, activity of hydrocarbon-oxidizing microorganisms, with the main products of biodegradation of petroleum hydrocarbons are carbon dioxide, water and biomass of microorganisms grown on hydrocarbons. Polymer and highly condensed branched, cyclic alkanes, and aromatic heterocyclic compounds or destroyed by oxidation or cooxidation very slowly. Oxidation of hydrocarbons occurs mainly intracellularly, so it is intrinsically linked to the nature of receipt of hydrocarbons into the cell.

Remediation activities include the creation of optimal conditions for the implementation of the above-mentioned transformations oil related primarily to the activities of microorganisms. Accelerate the clearing of the environment from oil pollution are two ways (Wei OY, 2005):

1) activation of the oxidative capacity of soil microorganisms by changing the physical and chemical conditions of the environment (agricultural activities);

2) the introduction into the soil and pond specially selected biologics based on hydrocarbon-oxidizing microorganisms.

When studying the technology of bioremediation of soils contaminated with petroleum hydrocarbons reported different levels of microbial activity in the experiments with different methods of remediation and weather and climatic conditions (Vasudevan, N. and Rajaram, P., 2001, Simon MA et al, 2004). The effectiveness of biological remediation, such as northern soils is hampered by severe climatic conditions: a long period of low temperatures, the large thickness of the snow cover, a small snow-free period, the acidic pH of the soil. In the context of South Kazakhstan difficulties in conducting bioremediation works are sharp seasonal variations in temperature: the warmer periods of up to $+50^{\circ} \mathrm{C}$, during cold periods-to $20^{\circ} \mathrm{C}$; arid climate and high soil salinity.

\section{Material and Methods}

Soil. Soil samples were collected from Refinery Limited Liability Company 'PetroKazahsta Oil Products' ('PKOP' LLP). Soil samples were used to analyse the physico-chemical parameters and to isolate the bacteria. Typical medium loamy soil-gray soils with different oil content. Selected oil contaminated soil and control the main parameters did not differ among themselves. The content of humus in these soils is 1.6-1.8\%, total nitrogen $\mathrm{N}$ (Kjeldahl) $0.146 \%$, the mobile P2O5 $38 \mathrm{mg} / \mathrm{kg}$ soil.

Collection of Samples: Samples were collected at a depth within $5 \mathrm{~cm}$ from the surface of the soil. They were collected in sterile polythene bags and tightly packed. They were then carefully transferred to the laboratory for analysis and stored at $4^{\circ} \mathrm{C}$ aseptically before processing.

Physico-Chemical Properties of Contaminated Soil: The soil physico-chemical parameters were analysed. Particle size analysis was carried out using the hydrometer method (Bouyocos, G.H., 1951). Soil texture was sandy loam. Soil $\mathrm{pH}$ was determined using a $\mathrm{pH}$ meter. The temperature of the soil samples was determined using a mercury thermometer. The electrical conductivity of the soil suspension was measured using the electronic digital conductivity meter. Total nitrogen was determined by kiedahl digestion and steam distillation method (Sankaram, A., 1996). Available phosphorous was determined by the method of Available micro nutrients were determined by the method of Olsen, S.R.et al. (1954).

Oil and diesel fuel. Oil Kumkol field, which is characterized by the following indicators: pour point $100 \mathrm{C}$, silica gel resin content of 19.2\%; carbo-karboides 5.82\%; $5.4 \%$ asphaltenes; wax $7.5 \% ; 0.064 \%$ sulfur. At a temperature of $200 \mathrm{C}$ has a density $-0.850 \mathrm{~g} / \mathrm{cm} 3$. Fractions low sulfur diesel fuel, acidity does not exceed $3 \%$. At a temperature of $200 \mathrm{C}$ has a density $-0.804 \mathrm{~g} / \mathrm{cm} 3$. The high content of $n$-alkanes (24\%).

Vermiculite - a natural mineral from the group hydromicas. It is formed in nature as a result of hydration and other secondary changes in various micas. An important property of vermiculite, which determines its commercial value - is the ability to grow in volume (swell) in $6-8$ times if heated above $300 \mathrm{OC}$. Exfoliated vermiculite has a number of valuable properties, among which the most important should include the following: low density - $80-200 \mathrm{~kg} / \mathrm{m} \mathrm{3}$, a low coefficient of thermal conductivity $-0.048-0.06 \mathrm{~W} / \mathrm{m} 0 \mathrm{C}$, high sound absorption coefficient at a frequency of $1000 \mathrm{~Hz}-0.7-0.8$, low coefficient of thermal expansion - - 0.000014 . The melting point of $1350^{\circ} \mathrm{C}$. Sorption volume - to $450 \%$. Chemical 
composition, \%: SiO2-34-36, AL203 - 6-18, MgO-14-25, CaO-1,2-2, K20 -3-5, Fe2O3-5,6-17, impurity -0.2 -1.2

Isolation and Enumeration of Bacteria: Isolation and enumeration of bacteria were performed by soil dilution plate technique using mineral salts agar media. One gram of dried soil was dissolved in $9 \mathrm{ml}$ of distilled water and agitated vigorously. Different aqueous dilutions, 10,10,10 of the suspension were applied on to plates and 20ml of melted medium at around $50^{\circ} \mathrm{C}$ was added to it. After gently rotating, the plates were incubated at $37^{\circ} \mathrm{C}$ for 24 hours. Enumeration of different isolates was carried out. Selected colonies of bacteria were transferred from mixed culture of the plates on to respective agar plates and incubated at $37^{\circ} \mathrm{C}$ for 24 hours. Plates containing pure cultures were stored at $4^{\circ} \mathrm{C}$ until for the examinations.

\section{Isolation and screening cultures}

a. Mineral salts medium (MSM)(g/L): K2HPO4 (2g), KH2PO4 (0.5g), NaCl $(0.5 g), \quad \mathrm{NH} 4 \mathrm{Cl}(0.5 \mathrm{~g}), \mathrm{MgSO} 4$ $(0.2 \mathrm{~g}), \mathrm{CaCl} 2(10 \mathrm{mg}), \mathrm{pH} 7.2$, containing different concentration of diesel and kumkol oil.

b. Enrichment medium(EM): meat extract, peptone culture medium and glucose medium.

c. Preservation medium(PM): meat extract, peptone, agar medium (MPA)

Characterization of Isolates: Each isolate was examined many times for its size, shape, margin, consistency opacity, elevation, pigmentation, Gram reaction and cell morphology as described by Holt et al(1994). Diagnostic properties used include motility, production of catalase, indole, urease, oxidative fermentation of sugars, methyl red test, voges proskauer test and citrate utilization test.

Biogenic additives. Under field conditions, the nitrogen and phosphorus were added as a $1 \%$ aqueous solution of monoammonium phosphate.

Remediation technique. Oily soil remediation technique included the following main activities: loosening (aeration) to a depth of 35-40 cm using a plow attached to a wheel tractor in tight spaces - manually. Microbial biomass and MAP were made by spraying a solution. Repeated loosening the soil was carried out at least once in 10 days, the next day after watering. Cleaned of soil moisture was maintained at $50-60 \%$ of its full capacity. Sawdust were added in an amount of 2-10 $\mathrm{t} /$ ha depending on the type and extent of oil pollution. Pilot tests were carried out under real production conditions in local areas of 'PKOP' LLP.

\section{Program of investigation}

To examine the feasibility of bioremediation of oil-contaminated soil at the Shymkent refinery 'PKOP'LLP program has been developed, consisting of the following stages: a preliminary assessment of the environmental situation in the company on the basis of chemical and microbiological analyzes; isolation and identification of hydrocarbon-oxidizing microorganisms; study of the kinetics of degradation of petroleum hydrocarbons and petroleum products; development of a biological product; conducting laboratory and pilot tests.

\section{Results and Discussion}

Preliminary assessments of oil pollution on soil TOO 'PKOP' showed that the oil content of the soil in the industrial area can vary from 1.0 to $25.0 \mathrm{~g} / 100 \mathrm{~g}$ of soil; on the production area - up to $1.0 \mathrm{~g} / 100 \mathrm{~g}$ of soil. It has been found that control of soil samples in composition autochthonous flora is dominated by bacteria whose number reaches 3-5 million cells/g. The number of spore-forming microflora during the entire period of remediation ranged from 1.0 to 1.8 million cells/g. In determining the proportion of hydrocarbon-oxidizing microorganisms in general, the composition of the soil microflora found that $30 \%$ of the microorganisms grown on meat-peptone agar (MPA), are able to use petroleum hydrocarbons as the sole source of carbon and energy. Comparative analysis of spontaneous microflora in clean (the area near the entrance and near the plant) and the various factions of contaminated oil soils showed that the number of major groups of heterotrophic bacteria in oil-contaminated soil has been reduced by $58-68 \%$, the number of actinomycetes by $71 \%$, spore-forming organisms by $68 \%$ that explains the toxic effect of oil on the activity of microorganisms. At the same time, resulting in chronic toxic effects of the microflora sufficiently homogeneous and presented by such genera as Pseudomonas, Micrococcus and several gram-positive rod-shaped bacteria. During the research accounted for spontaneous living in the soil hydrocarbon-oxidizing bacteria. Studies show that most of the heterotrophic microflora is concentrated in the $0-10 \mathrm{~cm}$ soil layer, which is understandable environmental factors favoring of life of this group of microorganisms: the access of oxygen, sufficient moisture, gas-air mode. As the depth of sampling to $20-30 \mathrm{~cm}, 30-40 \mathrm{~cm}$ titer of heterotrophic microorganisms is reduced by 1-2 orders of magnitude. Analysis of oil content in soil samples from various depths, showed that the highest concentration found in layers of $10-20 \mathrm{~cm}$ and less. In contrast, in areas contaminated with diesel fuel and fuel oil, the highest oil pollution and the number of microorganisms found in the 0-10 $\mathrm{cm}$ horizon.

As a result of screening of 145 cultures of micro-organisms on the consumption of xylene, toluene, hexadecane, 
benzene, naphthalene, anthracene was allocated 6 active microbial strains IS1, IS16, IS22, IS24, IS30, IS41. To enable sharing of strains in vitro was tested their activity by oxidation of $2 \%$ oil, either alone or in embodiments. Duration of experiment was 10 days. As a result of this experiment, it was found that the highest degree of oxidation of the oil $-99.3 \%$ owned by a consortium of strains IS16 and IS41, in accordance with Figure 1.

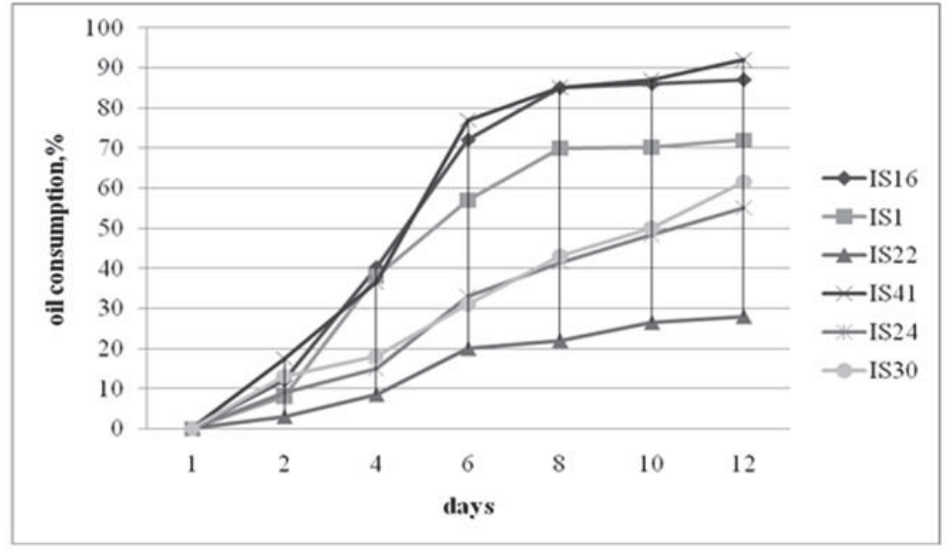

Figure 1. Dynamics of changes in titers of various strains of microorganisms in a medium with $2 \%$ oil

Taxonomic analysis showed that they belong to the species Micrococcus luteus IS16 and Micrococcus varians IS41.

Of physical and chemical conditions which activate the soil microflora, it is important to ensure microbial oxygen and nutrients like nitrogen and phosphorus. In real applications TOO 'PKOP' in the tank farm A was an experiment to study the effect of the isolated strains of microorganisms to reduce the concentration of oil in the soil. Duration of experiment was 90 days. With initial content of oil in the soil kumkol $101245 \mathrm{ug} / \mathrm{kg}$ in the control variant reduce the concentration of oil is almost not detected. Soil aeration reduced the oil content of $1.2 \%$. Activation of spontaneous microflora reduced the oil content of 39.6\%. Adding active biomass of microorganisms Micrococcus luteus IS16 and Micrococcus varians IS41 on a background of farming activities degraded $57.3 \%$ of petroleum products in the soil (Figure 2).

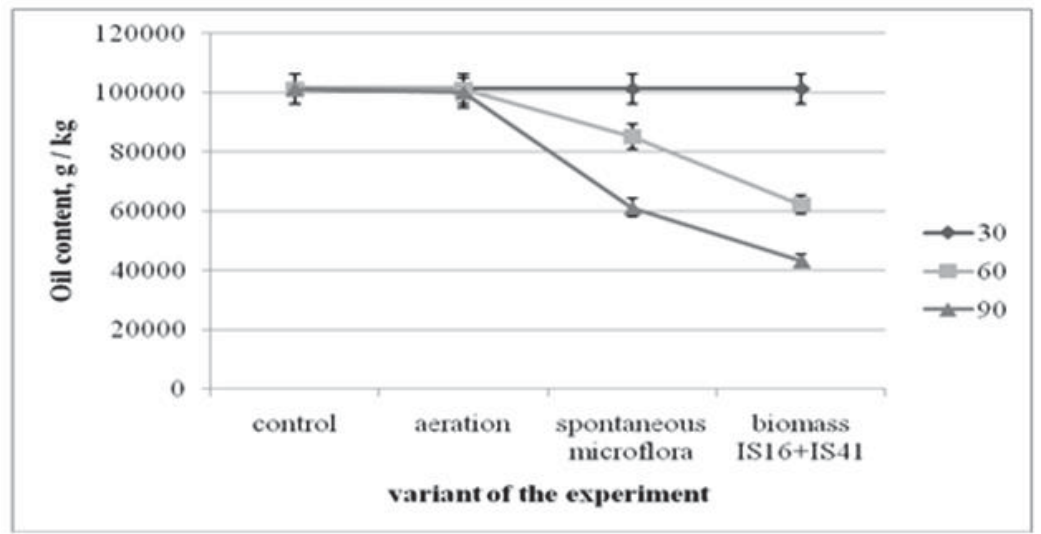

Figure 2: Dynamics of reduction of oil content in the soil

In field studies have investigated the possibility of using bentonite as an immobilizer for microorganisms. Immobilized microbial biomass contained $10^{8}$ cells / g microorganisms. To carry out work in the territory of 'PKOP' LLP identified a number of local areas with different content of diesel fuel. The density of the soil in the areas was $2.2 \mathrm{~g} / \mathrm{cm}^{3}$, however, to reduce it to one of the variants of the experiment were brought into the ground sawdust. As with the experimental results shown in Table 1, it is seen that reduction of the diesel fuel in the soil has introduction not only microorganisms, but also the introduction of sawdust as destructurator soil. Augmentation microorganisms reduces the content of diesel fuel to $47.5 \%$, supplementary destructurator -on 53.6\%, compared with the case where spontaneous activated microflora. 
Table 1: Effect of spontaneous and augmented to reduce the microflora content of the diesel fuel in the soil

\begin{tabular}{|c|c|c|c|c|c|}
\hline \multirow{2}{*}{$\#$} & variant & \multicolumn{2}{|c|}{ The content of diesel fuel in the soil, $\mathrm{mg} / \mathrm{kg}$} & \multicolumn{2}{c|}{ The efficiency of the diesel fuel degradation average, $\%$} \\
\cline { 3 - 6 } & control & 40 & 60 & 30 & 60 \\
\hline 1 & aeration & $401250,0 \pm 91,2$ & $43500,0 \pm 112,5$ & 0,1 & 0,2 \\
\hline 2 & $36600,0 \pm 48,6$ & $37680,0 \pm 102,6$ & 15,2 & 45,3 \\
\hline 3 & $\begin{array}{c}\text { aeration + ammophos } \\
\text { spontaneous microflora) }\end{array}$ & $28320,0 \pm 92,5$ & 22,6 & 92,8 \\
\hline 4 & $\begin{array}{c}\text { aeration + ammophos+ } \\
\text { microbial biomass }\end{array}$ & $18620,0 \pm 94,5$ & $6886,0 \pm 45,6$ & 60,6 & 98,9 \\
\hline 6 & $\begin{array}{c}\text { aeration + ammophos+ } \\
\text { microbial biomass +sawdust }\end{array}$ & $16320,0 \pm 98,5$ & $6730,0 \pm 36,8$ & 65,5 & \\
\hline
\end{tabular}

Sawdust further optimize the gas-air regime of soil, which creates favorable conditions for the life of augmented microorganisms. Furthermore, in all likelihood, they are an additional source of readily assimilable carbon source, cometabolism that under promotes the biodegradation of hydrocarbons of the diesel fuel.

\section{Conclusion}

Based on the obtained results showed that the titer of hydrocarbon-oxidizing soil microflora as correlated with the concentration of oil and qualitative composition of the oil pollution. In real applications TOO 'PKOP' the most favorable conditions for the life of hydrocarbon-oxidizing microflora: moisture, aeration, carbon diet - are created in the 0-10 cm horizon, which defined their highest titer. Of oil-contaminated soils LLP "PKOP" were isolated 2 strain hydrocarbonoxidizing microorganisms Micrococcus luteus IS16 and Micrococcus varians IS41, which are able to reduce the amount of oil kumkol by $57.3 \%$, diesel-on $92.8 \%$ in 2 months. The additional introduction of sawdust as destrukturator of soil reduces the content of diesel fuel in the soil for up to $98.9 \%$.

\section{Acknowledgments}

The authors express their gratitude to the staff of the Department of Ecology and labor protection TOO 'PetroKazakhstan Oil Products' Emberdiev Amanali and Manapova Nazipa for assisting in research at the plant.

\section{References}

Admon, S., Green, M., Avnimelech, Y. (2001). Biodegradation Kinetics of Hydrocarbons in Soil during Land Treatment of Oily Sludge. Bioremediation Journal No.5(3). Pp.193-209.

Ainon, H., Mohamad, Nik Mohd, N., Wan Yusoff, W.M. (2006). Petroleum hydrocarbon degrading bacteria from oil contaminated site: isolation, screening, identification and degradation studies. Proceeding 8th National Biological Symposium. Pp.1-6.

Anozie, O., Onwurah, I.N.E. (2001). Toxic effects of Bonny light crude oil in rats after ingestion of contaminated diet. Nigerian J. Biochemistry and Molecular Biology (Proceedings Supplement ). 16 (3). Pp.1035-1085.

Azlinah, M.S., Lee, K.C., Aishah, H., Chee, M.S., Darah, I., Ibrahim, C.O. (2008). Isolation, screening and identification of potential petroleum hydrocarbon degraders. Proceedings of the 6th Regional IMTGT-UNINET Conference. Pp.146-149.

Baker, J.M. (1983). Impact of Oil Pollution on Living Resources: Commission on Ecology Papers No 4 International Union for Conservation of Nature and Natural Resources, Gland, Switzerland.

Bouyocos, G.H. (1951). A recalibration of the hydrometer for making mechanical analysis of soils. Agron. J. No.43. Pp.434-438.

Chaineau, C.H., Yepremian, C., Vidalie, J.F., Ducreux, J., Ballerini, D. (2003). Bioremediation of Crude Polluted Soil: Biodegradation, Leaching and Toxicity Assessment. Water, Air and Soil Pollution 144. Pp.419-440.

Chaineau, C.H., Rougeux, G., Yepremian, C., Oudot, J. (2005). Effects of Nutrient Concentration on the Biodegradation of Crude Oil and Associated Microbial Populations in the Soil. Soil Biology \& Biochemistry. No.37. Pp.1490-1497.

Dibble, J.T, Bartha, R. (1979). Effect of Environmental parameters on the biodegradation of oil sludge. Appl. Environ. Microbiol. No.37. Pp.729-739.

Embar, K., Forgacs, C., Sivan, A. (2006). The role of indigenous bacterial and fungal soil populations in the biodegradation of crude oil in desert soil. Biodegradation. No.17. Pp.369-377.

Ilyina, A., Castillo Sanchez M.I., Villarreal Sanchez J.A., Ramirez Esquivel G. and Candelas Ramirez J. (2003). Isolation the soil bacteria for bioremediation of hydrocarbon contamination. Afr.J. Biotechnol. No.41(6). P.135.

Issayeva A.U., Rysbayeva G.A., Uspabayeva A.A., Eshibaev A.A. (2012). Biorecultivation of Oil-Contaminated Soils of South Kazakhstan. International Journal of Experimental Education. No.12. Pp.52-53. URL: www.rae.ru/meo/?section=content\&op= show_article\&article_id $=3281$ 
Gallego, J.L.R., Loredo, J., Llamas, J.F., Vasques, F., Sanchez, J. (2001). Bioremediation of diesel-contaminated soils: Evaluation of potential is situ techniques by study of bacterial degradation. Biodegradation. No.12. Pp.325-335.

Holt, J.G., Krieg, N.R., Sneath, P.H.A., Staley J.T. and Williams S.T. (1994). Bergey's Manual of Determinative Bacteriology. 9th Ed. Williams and Wilkins. Pp.71-561.

Mishra, S., Jyot, J., Kuhad, R.C., Lal, B. (2001). Evaluation of Inoculum Addition to Stimulate In Situ Bioremediation of Oily-Sludge Contaminated Soil. Applied and Environmental Microbiology. Pp.1675-1681.

Milic, J.S., Beskoski, V.P., Ilic, M.V, Ali, S.A.M., Gojgic-Cvijovic, G.D. and Vrvic, M.M. (2009). Bioremediation of Soil Heavily Contaminated With Crude Oil and Its Products: Composition of the Microbial Consortium. Journal of the Serbian Chemical Society. No.74. Pp.455-460.

Namkong, W., Hwang, E.Y., Park, J.S., Choi, J.Y. (2002). Bioremediation of diesel-contaminated soil with composting. Environmental Pollution. No.119(1). Pp.23-31.

Obayori, O.S., Adebusoye, S.A., Adewale, A.O., Oyetibo, G.O., Oluyemi, O.O., Amokun, R.A., Ilori, M.O. (2009). Differential degradation of crude oil (Bonny Light) by four Pseudomonas strains. Journal of Environmental Sciences. No.21. Pp.243-248.

Obuekwe, C.O., Al-Jadi, Z.K. and Al-Saleh, E.S., Al-Saleh, Esmaeil S. (2009). Hydrocarbon degradation in relation to cell-surface hydrophobicity among bacterial hydrocarbon degraders from petroleum-contaminated Kuwait desert environment," International Biodeterioration \&Biodegradation, Vol. 63, Apr. 2009, pp. 273-279, doi: 10. 1016/j. ibiod. 2008. 10. 004.

Okoh, A.I. (2006). Biodegradation alternative in the clean up of petroleum hydrocarbon pollutant Biotech. Mol. Biol. Rev. No.1(20). Pp.38-50.

Olsen, S.R., Cole, C.V., Watnab F.S. and Decan, L.A. (1954). Estimation of available phosphorous in soil by extra action with sodium bicarbonate U.S. Department of Agric. Pp.939.

Sankaram, A. (1996). A Laboratory manual for agricultural chemistry. Asia publishing house. Pp.340. New Dehli.

Simon, M.A., Bonner, J.S., Page, C.A., Townsend, R.T., Mueller, D.C., Fuller, C.B., Autenrieth, R.L. (2004). Evaluation of two commercial bioaugmentation products for enhanced removal of petroleum from a wetland. Ecological Engineering. No.22. Pp.263-277.

Vasudevan, N., Rajaram, P. (2001). Bioremediation of oil sludge-contaminated soil. Environment International. No.26. Pp.409-411.

Vega-Jarquin, C. (2001). Dengooven I., Magana-Plaza 1., Thalasso F., Ramas-Valdivia A. (2005). Biotransformation of n-hexadecane by cell suspension cultures of Cinchona robusta and Dioscorea composti. Environ. Toxicol. Chem. No.20. Pp.2670-2675.

Wei O.Y., Hong, L., Murygina, V., Yong, Y.Y., Zeng, D.X., Kalyuzhnyi, S. (2005). Comparison of bio-augmentation and composting for remediation of oily sludge: A field-scale study in China. Process Biochemistry. No.40. Pp.3763-3768. 